Garlick, Ben ORCID:

https://orcid.org/0000-0001-7257-0430 (2019) Cultural geographies of extinction: animal culture amongst Scottish ospreys. Transactions of the Institute of British Geographers, 44 (2). pp. 226-241.

Downloaded from: http://ray.yorksj.ac.uk/id/eprint/3306/

The version presented here may differ from the published version or version of record. If you intend to cite from the work you are advised to consult the publisher's version: https://doi.org/10.1111/tran.12268

Research at York St John (RaY) is an institutional repository. It supports the principles of open access by making the research outputs of the University available in digital form. Copyright of the items stored in RaY reside with the authors and/or other copyright owners. Users may access full text items free of charge, and may download a copy for private study or non-commercial research. For further reuse terms, see licence terms governing individual outputs. Institutional Repository Policy Statement

\title{
RaY
}

Research at the University of York St John

For more information please contact RaY at ray@yorksj.ac.uk 


\section{Cultural geographies of extinction: animal culture amongst Scottish 2 ospreys}

3 Ben Garlick

4 School of Humanities, Religion \& Philosophy, York St John University.

\section{Abstract}

6 This paper explores cultural geographies of extinction. I trace the decline of the

7 Scottish osprey during the nineteenth century, and its enduring, haunting presence

8 in the landscape today. Taking inspiration from the environmental humanities,

9 extinction is framed as an event affecting losses that exceed comprehension in terms

10 merely of biological species numbers and survival rates. Disavowing the 'species

11 thinking' of contemporary conservation biopolitics, the osprey's extinction story

12 pays attention to the worth of 'animal cultures'. Drawing a hybrid conceptual

13 framework from research in the environmental humanities, 'speculative' ethology

14 and more-than-human geographies, I champion an experimental attention to the

15 cultural geographies of animals in terms of historically contingent, communally

16 shared, spatial practices and attachments. In doing so, I propose nonhuman cultural

17 geographies as assemblages that matter, and which are fundamentally at stake in the 18 face of extinction.

19 Key Words

20 Extinction, Conservation, Cultural geography, More-than-human geography,

21 Osprey, Scotland 


\section{Introduction}

24 The species label Pandion haliaetus - the osprey - envelopes much lively difference 25 and possibility. Across four subspecies of this brown and white piscavore are 26 variations in size, markings and geographical behaviour. Furthermore, past and 27 present observations suggest multiple osprey life-ways are possible, expressed between, and within, these subspecies. Colonial behavior, for example, characterises certain communities (notably in North America) but not others, perhaps reflecting 30 prey or nest availability (Newton, 1979). In a similar vein, European and North 31 American ospreys (P.h. haliaetus and P.h. carolinensis) are migratory, whilst Australian (P.h. cristatus) and Caribbean (P.h. ridgwayi) birds are not. For mobile communities, annual seasonal refrains correspond with sea ice coverage; spring melts driving prey into northern shallows (Poole, 1989). For Scottish ospreys (my focus here), wintering grounds predominate on Africa's western coast. After an initial successful migration south, the young birds reside here for around three years before returning north to seek a mate and nest. Rearing young in summer, breeding adults depart come autumn (Dennis, 2008). Migration studies posit that favoured routes may be shared across generations and regional communities (see Dennis, 2008).

Regional differences, and preferences, suggest osprey lives are geographically contingent. This paper explores such contingency in the context of extinction. Paying

44 close, geographical attention to the lives of birds, I sketch the historical cultural geographies of the osprey in Scotland, from the late-eighteenth to the early-twenty- 
46 first century. Following calls for more 'beastly' geographies (Hodgetts and Lorimer,

47 2015) I take seriously the lived spatio-temporal particulars of osprey life. In conversation with recent work within the environmental humanities, I frame osprey differences in terms of an 'animal culture' both spatially and temporally contingent, and at stake amidst the unfolding geographies of extinction. Historical records of ospreys in Scotland reveal such differences, emergent over time, raising questions regarding the nature of extinction and loss.

Consider that in the early-nineteenth century the northern Scottish county of

Sutherland hosted a vibrant community of ospreys. In 1848, notorious sportsman and naturalist Charles St John travelled here with professional egg-collector William Dunbar (see St John, 1884). Visiting lochs where ospreys nested on ruins and rocky outcrops - including Assynt, 'an Laig Aird' (possibly Laicheard) and an Iasgair

(Figure 1) - they took eggs and shot several adult birds. Afterwards, Dunbar wrote to a southern client that they had 'finally done for the Ospreys in Sutherland'

61 (Harvie-Brown and MacPherson, 1904: 186).

62

63 Over a century later, in August 1961, George Waterston, Scotland's representative 64 for the Royal Society for the Protection of Birds, holidayed in northwest Sutherland. He had just overseen a third successful nesting season for the ospreys at Loch

66 Garten, Speyside. Dubbed 'Operation Osprey', re-colonising birds had raised young 67 in the Cairngorms under Society protections since 1959 (see Brown, 1979). Their 68 presence marked a return from 40 years of breeding extinction in Britain. Now 
stewarding the re-colonisation, it seems Waterston was curious to retrace St John's

70 footsteps. He drew on accounts of the 1848 tour when planning his own northern vacation. Waterston subsequently recalled his palpable excitement when standing 'almost exactly' where the infamous sportsman had once observed nesting ospreys

73 (Waterston, 1962: 113).

74

[Figure 1 - Map showing the location of Scottish nest sites discussed in this paper.

\section{Credit to L. Schofield]}

Whether scouting sites of potential re-colonisation or seeking sober reflection in remote surrounds, the account Waterston offers of his excursion in Sutherland conjures a profound curiosity for the ospreys' former geography and lifeworld. This historical vignette also raises a question: how should we reckon with such an

82 absence - less of a biological species than of a particular way of living - when that 83 which was absent comes back? This paper, with a desire to craft more interesting,

84 lively accounts of more-than-human historical geographies, argues in response for the need to appreciate extinction in terms beyond the species biopolitics of contemporary conservation. Considering questions of extinction with an eye on contemporary debates around reintroduction, re-wilding, and even 'de-extinction', geographers must attend to that which remains lost even after a species returns. 
91 Emerging out of a larger project seeking to explore the historical animal geographies

92 of Scottish osprey conservation (Garlick, 2017), this paper reads the insights of

93 scientific ornithology and empirical accounts of osprey life through a conceptual

94 framework rooted in contemporary literature around affect, neovitalist materialism,

95 biophilosophy and 'speculative ethology'. Thinking in speculative, risky and

96 creative ways about histories and cultures beyond the human foregrounds

97 important ethical questions about what is at stake in extinction.

98

99 My argument is based upon a speculative reading of the surviving traces and stories

100 of osprey presence, informed by the insights of a broader natural-scientific and

101 conservation literature concerning their behaviour, ecology and breeding biology. I

102 am alert to the contradiction here: seeking to challenge essentialist notions of species

103 whilst relying on literature steeped in this mode of understanding life and its

104 processes. This corpus enables me to better trace the activities and conditions

105 characteristic of osprey lived existence, such as it haunts the 'non-innocent'

106 eighteenth- and nineteenth-century documentary accounts of naturalists, travellers,

107 artists and sportsmen, comprising a nebulous 'animal archive' of ospreys in Scotland

108 (Benson, 2011).

109

110 However, I am careful not to allow such work to delimit a priori the capacities of

111 ospreys, or figure them transcendent of history and geography. Drawing on

112 scientific literature need not necessitate rigid adherence to a single scientific model, 
113 or overly circumscribe the possible forms that osprey behaviour might take (Lestel et

$114 a l, 2014)$. Rather, contemporary work on osprey ecology and conservation sharpens

115 attention to how animal existence and agency are historically assembled and

116 expressed in relation to a host of other actors and material conditions (Howell,

117 forthcoming).

118

119 Similarly, many discussions held during the course of research with individuals who

120 have spent time working with these birds likewise inform my understanding of 121 ospreys' capabilities (see Midgely, 1988). Stories of humans living and working with

122 birds past and present provide 'narratives of affiliation' (H. Lorimer, 2009: 65),

123 helping tune into the elements of the environment affecting, and affected by, animal

124 existence (J. Lorimer et al, 2017: 6). In sum, extant writing and reflection on ospreys,

125 by those who have spent years researching with them, assists me in asking the 'right

126 questions' of documents bearing their trace (Despret, 2016).

127

128 As much a geographical thought experiment as act of historical-cultural geography

129 scholarship, this paper seeks to fulfil the ambitions of a more-than-human history by

130 speculating on the historical conditions for (and of) osprey existence (Despret, 2013).

131 This is also an ethical project of imagination and recognition. Perhaps, as Dominique

132 Lestel argues, we attribute 'too much' to humans, and 'too little' to others in social

133 theory (2014b: 99). A little epistemological 'courtesy' (albeit critically informed and

134 reflexive [Johnston, 2008: 644-645]) might stem from the recognition that, in certain

135 ways and under certain conditions, animals are 'not so different from humans' (Philo 
and Wilbert, 2000: 25, original emphasis). I frame osprey life as active and

137 contingent: an outcome of situated involvements between birds, humans, and other agencies (after Woodward et al, 2010).

139

140 The aim is to write historical geography more attuned to ospreys' agential potential.

141 Rather than cry 'anthropomorphism!' I urge the reader to persist and consider the 142 questions such an account opens onto. A more lively account of past ecologies, I 143 argue, offers one route by which to mobilise the care required to live with, and 144 respond to, past and present environmental losses (see Tsing, 2015; Chrulew, 2011).

145 The alternative - divesting ospreys of lived experience and specificity - merely 146 'mechano-morphises' (Crist, 1999) creatures that, like ourselves, demonstrably 147 perceive the world, respond to it, and 'really are alive' (Ingold, 1994: xxi).

149 Over the following paper I attend to the more-than-human cultural geographies at 150 stake in extinction. I begin by establishing a conceptual framework that challenges 151 the 'species thinking' of conservation biopolitics and extends 'culture' beyond

152 humans. I then sketch the dimensions of a Scottish osprey 'cultural community' and 153 its unravelling until the point of eradication in 1916. Tracing a disjointed geography

154 of absence and presence, I emphasise the enduring losses that extinction (as the cessation of a 'way of life') affects, demonstrating why thinking with animal culture

156 alerts us to the continuing ethical significance of such loss today. 


\section{Extinction, culture and more-than-human geographies}

159

160

161

162

163

164

165

166

167

168

169

170

171

173

174

\section{Extinction beyond the biopolitical}

In contemporary wildlife conservation a creature's presence clearly matters, both actually recorded and potentially emergent (Hinchliffe, 2007). Yet, acts of classification, calculation, and distributional mapping often render such presence a series of multiple, differently valued, and sometimes contradictory collectives in (or across) space (Beirmann and Mansfield, 2014; Hodgetts, 2017). Such initiatives, read by geographers through Michel Foucault's 'biopolitics' (see Foucault, 2003), figure life primarily in terms of averaged characteristics, or norms. Despite a diversity of animal presence on the ground, overall conservation strategy deals in populations, and the massifying metrics of bio- or genetic diversity (J. Lorimer, 2006; Srinivasan, 2014; Hennessey, 2015).

Since the mid twentieth century contemporary conservation has been increasingly defined by the perception of an encroaching, human-instigated, 'sixth mass extinction' that it seeks to prevent (Adams, 2004; Kolbert, 2014). Extinction labels collective annihilation - potentially of entire taxa (see Smith-Patten et al, 2015). Whilst background rates of extinction may be 'ecologically necessary' - with fossil records suggests a species disappearance on average every four years, creating space for (better adapted) others to flourish -identified mass extinction events (where disappearance rates reach 50-1000 times background levels) indicate episodes of extreme ecological upheaval, generating much scientific and cultural interest (Heise, 2010). 
182 Despite any extinction event entailing multiple, situated stories of decline - such as

183 that of the Sutherland ospreys - lived differences dissolve with losses rendered in

184 terms of quantifiable biological species units. In much conservation discourse, 185 extinction is enacted through numbers. Calculations of vulnerability prioritise what 186 must be saved. The 'Red List', compiled by the International Union for the

187 Conservation of Nature since 1964 (see IUCN, 2012), exemplifies this biopolitical 188 (and ethical) triage in action (Pooley, 2015). Meanwhile, conservation looks to 189 genetics to promote new measures of collective diversity (or value) at molecular 190 scales (Waterton et al, 2013; Hennessey, 2015). Hybrid forms compromising genetic 191 purity are suppressed (Fredriksen, 2016). Violent incarcerations (and inseminations) 192 accompany attempts to care for fragmented, remnant populations of rare species 193 (van Dooren, 2014; Chrulew, 2011). Threatened creatures circulate through multiple 194 spaces including digital databases, zoos and re-introduction centres (Whatmore and 195 Thorne, 2000; Braverman, 2015). There remains limited scope for care-full attention 196 to lived animal geographies within this biopolitical schema.

198 Marshalling recent humanities scholarship, I pay a different kind of attention to 199 species life and death. Specfiically, work within 'extinction studies' (Rose et al, 2017 200 further expanded below) offers opportunities for staying with the particularities of 201 past osprey presence, and telling the story of the Scottish birds' decline and return 202 whilst, at the same time, keeping hold of what remains lost. Grouping creatures into 203 collectives on the basis of apparently essential qualities renders them mere 'units of 
exchange' (Mitchell, 2016: 34), ultimately 'killable' to secure species wellbeing 205 (Haraway, 2008; Srinivasan, 2014). Yet crucially, such 'species thinking' fails 'absolutely' to recognise 'what [...] is actually lost' through extinction (van Dooren, 2010: 272). The vital relations and contingent differences comprising actual ways of living - what Thom van Dooren terms 'flight ways' (2014) - are excluded from any such biopolitical reckoning with environmental destruction. Writing within the environmental humanities (Rose et al, 2017), as well as geography (see Van Patter

211 and Hovorka, 2018: 291), has challenged species essentialism and concomitant

212 conservation discourses of the 'greater good'. Increasingly, 'species' - as atomised

213 units of concern and a 'concrete phenomenon of nature' (Mayr, 1996: 263) - become

214 'unthinkable' within posthumanism's rhizomatic ontologies (Haraway, 2016: 57;

215 Whatmore, 2002).

216 More-than-human cultural geographies

217 To expand a sense of what is at stake in extinction, I make geographical and

218 historically specific osprey 'ways of living' tangible through the notion of 'animal

219 culture'. 'More-than-representational' (Lorimer, 2005) cultural geographies are just 220 as evidently 'more-than-human' (Whatmore, 2006; J. Lorimer et al, 2017). They elude explanation merely in terms of autonomous, exceptional human figures (Whatmore, 2002; Hird, 2010; K. Anderson, 2014). Given 'making worlds is not limited to humans' (Tsing, 2015: 22), consideration of osprey culture is entirely appropriate amidst geographical scholarship long attendant to ways of living, doing and distributing natures (Anderson et al, 2002; Kirsch, 2014). 
And yet, concern with 'culture' in geography remains largely human-focussed (Anderson et al, 2002: 18-21; Anderson, 2014; Hodgetts and Lorimer, 2015). Meanwhile, biologists, particularly primatologists and cetologists, have long debated

230 the existence of nonhuman cultures (see Laland and Galef, 2009; Whitehead and 231 Rendell, 2015). Indeed, culture appears a practical (if implicit) consideration for 232 many conservation scientists. Van Dooren $(2014 ; 2016)$ describes various instances where the management of captive-bred birds - such as crows and cranes - involves carefully supporting the development of an 'authentic' species being comprising the behaviours, perceptions and vocalisations that encompass a 'wild' subjectivity. Such examples feature plastic animal subjects, and testify to the multiple forms of 'animality' possible within different assemblages(Lestel, 2002).

239 Championing early critical attention to animal geographies, Chris Philo and Chris

240 Wilbert emphasised the need for attention to animals' own geographies - their

241 'beastly places' (2000: 5) - alongside the social construction of 'animal spaces'.

242 Although methodological and conceptual developments have favoured the former

243 (Hodgetts and Lorimer, 2015), there is growing energy within more-than-human geography to explore the spatial character of animal life beyond its 'placing' by

245 humans (H. Lorimer, 2006; Johnston, 2008; Buller, 2014, Buller, 2015; Van Patter and 246 Hovorka, 2018; J. Lorimer et al, 2017). Animals, figured as 'geographers too' (Buller,

247 2015: 380), enact spatial lives and attachments. Birds, recognised as 'geographical creatures' (Steinberg, 2010: iii), invest significance in place through migratory 
refrains, perceptions and attachments. Such geographies characterise the 'flight way'

250 of osprey existence.

251

252 Through the osprey's story I challenge the 'residual humanism' (Lulka, 2009) 253 surrounding cultural geography's central concept: culture. I argue that avian 254 cultures reflect creative capacities to find diverse ways of inhabiting with (or 255 against) the limits of an environment, demonstrating non-linear, 'affective', ecologies

256 (Hustak and Myers, 2012). They take material form through 'non-essential' 257 behavioural adjustments - such as nest preferences - shared socially between groups 258 of birds, and with neither genetics nor environmental factors providing a 'truly 259 satisfying' explanation of their appearance (Lestel, 2014b: 98). Thus, ospreys have a

260 heritage exceeding biology, including group traditions, spatial arrangements and 261 individual experience (Lestel, 2011: 84), which constitutes their very 'personhood' 262 (Ingold, 1994).

264 I engage osprey cultural geographies via a hybrid conceptual frame (see Hovorka, 2017) drawing inspiration from 'speculative' approaches to ethology (the science of animal behaviour). Such work continues the maverick, creative, creaturely spirit

267 championed by early pioneers of ethological study (see H. Lorimer, 2009). Rejecting a traditional, 'Cartesian-realist' ethology equating behavioural signals with fixed, 269 universalising behavioural models, scholars including Vinciane Despret and 270 Dominique Lestel propose a more open-ended consideration of animals, and their 271 capacity to form contingent communities of meaning and relating (Despret, 2013). 
272 Agential capacities are 'characterised by their historicity' (Lestel, 2002: 58), and 273 constitute an open, empirical question (Despret, 2006).

275 Culture is thus figured with an emphasis on affect and sense (Lestel, 2014b: 95). I emphasise a corporeal reading of 'affect', foregrounding: the body's capacity to 277 register the impress of worldly forces; the manner in which such impressions mediate a body's potential capabilities; and the various forces that emanate from

279 bodies to enact similar mediations upon surroundings and other bodies (Anderson, 2014). Specifically, I apply Sara Ahmed's concept of 'orientation' to characterize

281 'different ways of registering the proximity of objects and others' (Ahmed, 2006: 3)

282 as subjects affect and are affected by worlds. Orientations capture how spaces are 283 affectively inhabited: the aspects towards which the body extends, or from which it 284 retracts (Ahmed, 2010: 29). I (and others - Wright, 2015) see value in extending 285 Ahmed's thinking beyond humans. In an account of past and present osprey 286 nesting, orientation directs attention to the specific affects of a bird's worldy 287 situation, its 'point of view' (Ahmed, 2006: 12) as an emergent, multi-sensory, 288 perceptual attunement (Stewart, 2011).

290 In this manner, animal - specifically, avian - cultural life might be mapped, as 291 Deleuze and Guattari suggest, by virtue of 'counting its affects' (2013: 299). That is, 292 by documenting site- and relationally-specific ways of living as part of always293 hybrid communities (Lestel, 2014a); or through attention to the (re)articulation of 294 animal being amidst particular 'atmospheres' or fields of forces (J. Lorimer et al, 
2017). Exploring more-than-human cultural geographies therefore requires attention

296 to processes of 'learning to be affected' by the world, as to mediate future meetings 297 (Despret, 2004: 131). Arising from assembled agential capacities to perceive and 298 respond, 'different worlds [...] come into view'. In turning toward these worldly 299 offerings, bodies acquire 'the very shape of their direction' (Ahmed, 2006: 15-16).

300 Understanding encounters with place, objects or 'others' requires situating subjects amidst 'conditions of their arrival' (Ahmed, 2010: 33) and histories of relating. How

302 ospreys and nest sites become available to each other is a contingent process. Bodies and places are entrained into the refrains of migration, assembly and return, weaving together a creaturely ecology (H. Lorimer, 2009).

305

306 Osprey nesting geographies cohere as 'traditions' - social learning across 307 generations (McGrew, 2009) - marking out specific forms of difference within the 308 blanket category of 'genetic species'. These geographies emerge through the accumulation of more-than-human traces - nests, perches, migration routes, feeding

310 grounds. In turn, attention to traces and trajectories proposes an ecology of dynamic

311 places, as opposed to static habitats (Massey, 2005; van Dooren and Rose, 2012: 10).

313 To conclude this section: cultural geography - in concert with scholarship drawn

314 from across the environmental humanities - has both scope and resource to engage

315 more-than-human culture. The specifics of 'nonhuman' presence matter, revealing 316 difference and diversity (see Lulka, 2009: 382). Attention to animal culture means 317 examining how orientations of creaturely being emerge in relation and become 
sustained through inheritance. Over the remainder of the paper I discuss the osprey

319 in Scotland, making specific lives (and losses) visible and significant amidst processes of mass death.

\section{An osprey cultural community}

323 Ospreys are creatures with the capacity to form, share and inherit place attachments.

324 On the basis of shared orientations towards 'nestable' sites I advance the claim that nineteenth-century Scottish ospreys constituted a now-lost cultural community.

327 Nesting is a fundament of bird life, offering containment, insulation and protection

328 for eggs and young (Hansell, 2000). Sites of vital reproductive work (biological and cultural), nests are 'key nodes' (Reinert, 2013: 17) connecting individual existence to

330 the assemblage of collective being (Chrulew, 2011: 147). One can understand nests as

331 'animal architecture': nonhuman structures affecting local stability amidst volatile 332 environmental conditions (Hansell, 2000). Richard Dawkins theorises such

333 constructions in terms of an 'extended phenotype': the blueprints for building being 334 genetically encoded, as much a reflection of evolutionary development as 335 physiological capacities (Dawkins, 1982 in Ingold, 2000). Today, however, biologists emphasise multiple inheritance systems beyond the genetic (e.g. Laland and Galef, 337 2009). Nests offer an example of 'niche construction'. Coined by biologist John 338 Odling-Smee, this concept refers to species' capacities for altering environments, 339 maintaining spaces across generations that mediate selection pressures and enable 
340 the emergence - and persistence - of particular forms of (social) life (Laland et al, 341 2016).

343 My own speculative reading frames situated niche-building by a particular group of

344 the same 'species' as demonstrative of cultural diversity. I follow Tim Ingold (2000:

345 175) in rejecting the genetic essentialism of 'extended phenotypes', treating animal 346 dwelling as embodied, perceptive, active.

348 Cultures of nesting

349 Ospreys historically display wide-ranging recognition for 'nestable' places. By 350 nestable I mean evoking the capacities for successful nesting. This definition is 351 derived from Gaston Bachelard's phenomenological account of nesting as the 352 expression of locatable 'confidence in the world' (1994: 94-103). Crucially, such a 353 phenomenology defers to the animal: I place significance in where (and how) ospreys direct perception.

356 Cultural activity is embodied: the potential capacities of creatures in relation to 357 environmental affordances define the limits of emergent cultural permutations 358 (Lestel, 2014b). Consequently, commonalities exist between osprey nest sites globally. Proximate $(<20 \mathrm{~km})$, plentiful fishing is key. Likewise, many birds favour

360 prominent, elevated, open sites: 'landmarks' for human and osprey alike (Poole, 1989: 85). Such features offer easier landings when laden with prey, and a vantage to

362 spot intruders (Hardrey et al, 2009). Being large raptors, osprey eyries (nest 
structures) often exceed a metre in diameter. Viable sites offer a stable base for the

364 amassed sticks (and supplementary materials) held together by friction (Dennis, 365 2008).

367 Many places have hosted ospreys, so how do differences in site preference emerge?

368 Some attention is given to the affects of site attachment in accounts of osprey nesting, noting the 'magical attraction' (Poole, 1989: 89) of 'special places' (Newton, 1979: 39). I offer here a speculative account of nesting processes, contextualising ospreys within their affective ecologies, and connecting emergent orientations to site within birds' unfolding 'lifelines' (Ahmed, 2006: 17).

373

374 In forming attachments to specific places, male ospreys demonstrate a particular tendency to display 'natal philopatry': upon maturity they are likely to return to

376 their 'birth region' to breed. Sightings and recoveries of colour-ringed ospreys in

377 Scotland found 25 of 29 recorded birds nesting within $50 \mathrm{~km}$ of their natal site - and 37817 within 25km (compared to 2 of 34 females) (Dennis, 2008: 109). Results from 379 studies involying the ringing of Fennoscandian ospreys propose that 'a circle drawn 380 at $50 \mathrm{~km}$ radius of the birth place' would account for over $40 \%$ of ospreys, again 381 reflecting the propensity for male birds to inherit attachments to place (Newton, 382 1979: 176). With regard to attachments to particular nesting situations, young ospreys 383 show a preference for sites echoing the characteristics of natal nests. Such a process 384 of 'imprinting to area' (Newton, 1979: 282) is elsewhere evoked to explain, for 385 example, the increasing colonisation of utility structures across generations by 
ospreys in Europe (Meyburg et al, 1996). It is suggested that early flights from the nest might orient fledgling ospreys to their surroundings, making 'sticky' (Ahmed, 2010) certain features within emergent avian geographical perceptions. Together, such mechanisms demonstrate young ospreys' 'ontological openness' (van Dooren, 2014: 102) for geography.

Once a pair of ospreys has settled a site they will generally return to the same nest annually, so long as both survive migration and the site remains productive (Poole, 1989). In this way, as adults maintain eyries, preferences for region (through male progeny) and nesting situation become inheritable. Subsequently, orientations towards particular kinds of nest site emerge as 'local traditions of preference'

397 (Newton, 1979: 82; Poole, 1989: 89).

399 Osprey nesting preference thus enacts landscape as a communally-inherited, 400 'learned skill' (H. Lorimer, 2006: 504) and recognition of the post-fledging period as 401 crucial for assembling the geographical subjectivity of young ospreys informs the 402 contemporary practice of translocation. From 1996 to 2005 young ospreys were taken from Scottish nests, cage-reared at Rutland Water, Oakham, and released at the 404 point of fledging. From 2001, the first of these birds returned to nest, establishing a 405 breeding population here (Mackrill et al, 2012). Given natal philopatry is unevenly

406 observed (and varyingly expressed) an additional outcome of this project included 407 the tandem emergence of an osprey community in Wales with dispersal on return 408 migration. 
410 The relocation example attests that despite certain tendencies being recorded,

411 geographical orientations are not pre-given. Rather, nesting geographies remain

412 contingent over the life-course, textured by osprey experience, even 'memory' (see

413 Despret and Meuret, 2016). Site faith is tied to the persistence of seasonal

414 monogamy. If birds die on migration their remaining partners will likely return,

415 drawn north by an enduring place association. Equally, sites can be abandoned if

416 eggs or young are lost due to extra-species intrusions or storms (Hardey et al, 2009).

417 In this way, nests are (re)opened to colonisation by roving, nestless birds, entrained

418 into new sets of osprey relations. A site's 'stickiness' for particular individuals

419 reflects an on-going, creaturely storying of place (van Dooren and Rose, 2012). I turn

420 to explore such processes at work amongst the ospreys of nineteenth-century

421 Scotland.

422

423 Scottish osprey culture

424 Several authors label the demise of the Scottish osprey as 'extinction' (Brown, 1979;

425 Poole, 1989; Kitchener, 1998; Dennis, 2008). Yet, within a biological species-centred

426 definition of extinction such loss would be termed 'extirpation': the eradication of a

427 given population of a species 'in a specific area' (Smith-Patten et al, 2015: 482).

428 Extirpation implies that losses only register significance if genetic survival or

429 diversity is threatened. Here, in developing a conception of extinction in which ways

430 of life are at stake, I problematise extirpation as a concept for the way in which it

431 renders disparate populations interchangeable. 
433 Extinction studies scholarship challenges the essentialism inherent to biological

434 definitions of species, expanding the registers of significant loss (Mitchell, 2016).

435 Doing so requires telling alternative 'extinction stories': offering generative openings 436 (van Dooren, 2010: 272-273) onto the 'intimate peculiarities' of environmental 437 destruction (van Dooren, 2014: 7-8; Rose et al, 2017). Extinction is refigured as a 438 broader, slower process of detachment from conditions of dwelling in which the end 439 of a way of life precedes the disappearance of the last, lingering one (Rose, 2012). 440 Absence is felt beyond the biological, encompassing lost vocabularies, behaviours, 441 sensory knowledges and future possibilities (Smith, 2013). Recognising such losses 442 attests to more-than-human lives lived amidst relational communities, characterised 443 by situated forms of animal existence and worlding (see Yusoff, 2012: 587). As 444 Despret and Meuret articulate:

446 'Extinction begins when the world to which an animal was associated is reduced to 447 nothing, or almost nothing. Extinction begins when the ways an animal composes 448 the world and composes with the world are ended, when the ways he or she makes 449 a world exist, according to the ways his or her ancestors had created it, have 450 disappeared' (2016: 28-29)

452 In this spirit, I characterise the nineteenth-century Scottish osprey and its eradication 453 with reference to a collectively constituted orientation towards place. Doing so 454 makes legible osprey cultural geographies as a register of significant loss. 
456 Prior to disappearance in the early twentieth century, there is limited data regarding 457 the osprey's extent in Britain. Virtually no records precede the 1800s (Waterston, 458 1962). Likewise, there is little evidence as to its persecution, particularly outside of 459 Scotland. By 1800 the birds had probably disappeared from Ireland and a handful 460 remained in England until 1847 (Lovegrove, 2007). A clear (if loosely documented) 461 trajectory of decline accompanies this geographical contraction. With the osprey 462 confined effectively to Scotland by 1850, one estimate puts their numbers between 40 463 and 50 breeding pairs (Dennis, 1991). The same year, however, other writers note the 464 ultimate demise of the Sutherland-based population (see Brown, 1979; Lovegrove, 465 2007) described barely a decade earlier by Scottish naturalist William Jardine as so 466 abundant that one might see four or five birds a day in certain localities (Waterston, 1962: 81; also Selby, 1836: 287). By 1895 there were at most four pairs nesting 468 (Harvie-Brown and Buckley, 1895: 71). This had declined to just two by the early years of the twentieth century (see Cameron, 1948), and a final (recorded) pair bred 470 at Loch Loyne in 1916 (Gordon, 1949).

472 A notable feature of nineteenth-century accounts documenting encounters with 473 Scottish ospreys is their descriptions of nests, which suggest particular site 474 preferences. In northwest Sutherland, ospreys nesting on rock and ruin sites - rather 475 than the trees recorded elsewhere - were apparently common. For example, in 476 Charles St John's (1863: 138) writing he describes eyries 'placed either on the highest 477 part of some old ruin, on the peak of some rock which stands out from the water in a 
lonely highland loch, or, rarely on the very summit of an old tree'. Elsewhere,

479 Jardine alleged to only have observed such behaviour, asserting Scottish nests were 480 'always' sited on ruined structures (Jardine, 1838: 184). Despite trees in abundance, 481 ruins were 'preferred if near' (Jardine, 1832 quoted by Yarrell, 1871). Similarly, ornithologist William Yarrell, writing five years later, endorsed Jardine's

483 descriptions.Nesting ospreys are recalled on 'rocky islets' and 'old ruins', only 484 'sometimes on high trees' (1871: 32). In 1879, one newspaper article boldly claimed 485 ospreys built on trees only where ruins or rocks were not available ('Loch-an-Eilan 486 and its Ospreys', 9 June 1879). That rocks and ruins were central to natural

487 historians' understanding of the Scottish osprey, suggests their prominence within 488 the birds' own spatial perception during this period.

490 Ruin eyries offer an early example of the osprey's widely documented adaptability 491 to local conditions. The earliest record of ruin nesting occurs in the late-eighteenth492 century travel writing of Welsh naturalist Thomas Pennant (Baxter and Rintoul, 493 1954). At Loch Lomond, he describes 'sea eagles'1 that 'quit the country in winter' 494 nesting on the ruins of Inchgalbraith island (Pennant, 1771: 80). Their presence is corroborated in other late-eighteenth-century accounts - notably the writings of 496 Samuel Johnson, and within Gilpin's Observations on the Picturesque, compiled 1776 497 (1792: 27). Birds allegedly returned here until at least 1840 (Colquhoun, 1840), 498 suggesting cross-generational inhabitancy. In the diaries of Elizabeth Grant (1972:

\footnotetext{
1 Whilst Pennant describes the birds as 'sea eagles', it is generally accepted that he was referring to ospreys (Pandion haliaetus) and not white-tailed eagles (Haliaetus albicilla), also persecuted during this period (see discussion in Baxter and Rintoul, 1954).
} 
60) - of the Grants owning Rothiemurchus estate, Speyside - ospreys appear nesting

500 atop ruins at Loch an Eilein in 1808. Like Inchgalbraith, this site was long tenanted; ospreys appearing here (with periods of absence) until 1902 (Cash, 1914).

Many of the structures reportedly colonised - including Kilchurn Castle, Loch Awe

504 (Pearson, 1987); Lochindorb Castle, Lochindorb (Wilson, 2007); and Ardvreck Castle, certainly in a ruined state by the nineteenth century (see Simpson, 1937). As emerged for recombinant osprey ecologies. The avian attraction of such sites is clear: they were (relatively) stable, prominent, and often near water. I speculate that the

510 perception of ruins as 'nestable' may reflect their resonance with the form of those

511 rock sites utilised elsewhere. In such a reading, a distinctive culture of nesting 512 emerges at the 'contact zone' (Haraway, 2008) between birds and the detritus of

513 human activity, subsequently propagated across generations.

515 The distribution of this practice, and its documented persistence amidst periods of absence and re-colonisation, suggests rock and ruin nesting was not exceptional but

517 typical of this osprey community. Sites were made recognisable according to the 518 involvements orienting avian sensibilities to place. Once settled, the on-going 519 association between birds and site emerged via the affects of nesting elaborated 520 above. Ospreys nested on tree sites too (as observed today) but this does not 521 contradict a claim that their spatial perception of nestable landscapes was 
demonstrably different. If we understand extinction to result in a 'diminishment of

523 the prospects for becoming' (Whale and Ginn, 2017: 98) then the demise of the

524 Scottish osprey is significant, their absence marking the end of a particular kind of

525 being.

526

527 Unravelling a cultural community

528 Conceptualising osprey existence as a communally-sustained way of life better-

529 captures what is at stake in extinction. Attention to animals' geographies

530 foregrounds the lived spatiality of extinction stories. Scottish ospreys, as a cultural

531 community, would become extinct as intergenerational ties were severed or

532 unravelled (van Dooren, 2014: 22-27). Where survival necessitated the forging of

533 'liveable collaborations' (Tsing, 2015: 28), osprey deaths occurred as violent and

534 death-filled relations proliferated. Importantly, the geographies and affects of

535 human-led extinctions appear less spectacular or discrete than the distributed

536 aggregate of 'business as usual' (Yusoff, 2012). The extinction of osprey culture

537 occurred with a sustained and cumulative violence enacted across lived geographies

538 and down through generations. ${ }^{2}$

539

\footnotetext{
${ }^{2}$ Due to the constraints of space this paper focuses primarily on the impacts of persecution carried out against ospreys in Britain and Ireland, rather than across the full stretch of their migratory geographies between Britain and West Africa.
} 
541 In the nineteenth century, two sources of persecution emerged and combined to

542 whittle away osprey existence. The first was a natural history epistemology of

543 specimen collection, credited with fragmenting populations in the north. The second

544 was highland sport, linked to the killing of ospreys on managed estate lands at the 545 nest and on migration (McGowan, 2009).

547 Regarding collecting naturalism: a specific enthusiasm for the study and

548 classification of birds, emerging from the late eighteenth century, was predicated 549 upon the categorisation and comparison of specimens and eggs (see Farber, 1997).

550 Charles St John and William Dunbar's Sutherland tour typifies the 'peak' of such 551 collecting enthusiasm during the 1840s, allegedly contributing to the near-total 552 annihilation of the region's ospreys. Collectors also visited other well-known sites, 553 such as Loch an Eilein (see Harvie-Brown and Buckley, 1895: 75). There, the nest was 554 robbed by collector Lewis Dunbar (brother to St John's companion) annually from 555 1848 to 1852, his spoils going to southern clients (Wolley and Newton, 1864: 58-66).

556 Such actions prompted the ospreys to desert the ruin for over two decades (Cash, 1914).

Alongside collecting, ospreys suffered the wrath of landowners managing estates for 560 Highland sport. The arrival of the Royal Family on Deeside popularised a nature561 culture of romantic Highlandism, including the hunting of red deer (Cervus elaphus) and grouse (Lagopus lagopus scotica) (Pringle, 1988). Hired gamekeepers zealously 
563 pursued all raptors as 'vermin', fearing the propensity of some to predate game

564 (Lovegrove, 2007). Definitive figures for such destruction are elusive, with limited 565 information sourced from surviving estate and taxidermists' books (see McGhie, 566 1999). Oft-quoted records for Glengarry estate between 1837-1840 suggest the scale 567 of persecution: over three years 1,498 birds of prey were killed, including 18 ospreys 568 (given in Ellice, 1898: 27). Appreciating that by 1850 the entire Scottish community 569 likely comprised $40-50$ breeding pairs, such figures suggest major losses on estate 570 lands.

572 The relationship between osprey nesting culture and the impacts of persecution is 573 hard to determine. Their nests may have been more accessible than those of other 574 raptors (see Selby, 1836: 286). Moreover, a strong 'faith' for nests and favoured 575 perches made them easier to kill or trap (Lovegrove, 2007: 107). Sportsman John 576 Colquhoun recalls how, 'aware of their habit', he rowed to Inchgalbraith ruin, waited, and killed both ospreys upon their return, emptying a site 'occupied for generations' (Colquhoun, 1840: 86-7).

581 On some estates ospreys were given sanctuary. Eyries around Loch Arkaig were 582 protected under instructions from laird Donald Cameron of Locheil until abandoned 583 in 1914 (Cameron, 1948). At Loch an Eilein, resident ospreys were celebrated by early-century artists and travelers in search of the picturesque (see MacCulloch, 585 1824: 400; Beattie, 1834: 75). After visiting in 1879, HM Inspector for Schools William 
Jolly, writing for The Scotsman, bid the public, 'go to Rothiemurchus!' where they

587 might come as close to the birds as to 'a specimen in a museum' ('Loch an Eilan', 1879: 5). Subsequent tourist interest stimulated the estate's proprietors to safeguard the nest, banning boats on the loch and setting keepers on watch (see Lambert, 2001).

590

591 Despite attempts to prevent persecution, 15 of 24 recorded osprey breeding attempts 592 at Loch an Eilein between 1846 and 1899 culminate with eggs being taken (Ritchie,

593 1920: 192). The removal of eggs likely spelled the end of the season. Given threats 594 faced on migration - estimate mortality rates for ospreys in the first year, derived 595 from observations in the Eastern USA, are around 57\% (Newton, 1979: 368) - any 596 disruption to reproduction threatened a small community's capacity to endure. By 5971871 the osprey was being described as 'the rarest of our native species' (Gray, 1871: 598 18),

599

600 Even where successful, isolated protections achieved little given the mobile lives of 601 ospreys spanned a seasonal, migratory refrain. As early as the 1810s migrating 602 ospreys were shot annually in southern counties (Montagu, 1831: 347). The killing of 603 birds on the move evokes recent criticism of 'static' conservation initiatives that fail 604 to recognise animal mobilities (see Lulka, 2004; Reinert, 2015). The osprey's existence 605 in Scotland was sustained through a migratory assemblage. Death en route was not a 606 discrete event, but affected a delocalised, 'reverberating absence' (Reinert, 2015: 52) 607 felt through diminishing returns over following seasons. In autumn, birds travelling 
south stopped to roost or fish in less-friendly landscapes (see Harvie-Brown, 1896;

609 Dennis, 2008).

610

611 Ospreys 'slipped through the cracks' of legal frameworks intended to protect them 612 (see Srinivasan 2013: 109). The earliest legislation to offer blanket protection to wild 613 birds, introduced in 1880, did little to stem the killing unless local councils granted 614 special protections. However, by 1896 extra protection applied to a handful of UK 615 counties. A leaflet published by the fledgling 'Society for the Protection of Birds' the 616 same year decried this 'patchwork' of legislation as fatally mismatched to avian 617 flight-ways (Harvie-Brown, 1896). Protections fitted to human political boundaries 618 did little for birds running 'a gauntlet of innumerable shotguns' (Kearton, 1899: 61) 619 across a mobile, migratory geography (Lulka, 2004).

621 The maintenance of an osprey nesting culture required annual supplies of 'young blood' (Harvie-Brown and MacPherson, 1904: 204). Yet at home, and on passage, the community was diminishing. In the final 12 years of attempted breeding at Loch an

624 Eilein, just five produced young. In both 1888 and 1896, intruding ospreys instigated 625 skirmishes in which the eggs were smashed (and, in 1888, a female was killed)

626 (Cash, 1914: 115). The result was a frayed, precarious existence for birds at the 627 'edge' of extinction (van Dooren, 2014). The last pair to breed at Loch an Eilein did 628 so in 1899, though single ospreys appeared until 1902. Elsewhere, they bred at Loch 629 Arkaig until 1910 and Loch Loyne until 1916. A significant and specific form of 630 osprey culture had vanished. 


\section{Hauntings of osprey culture}

633 Today, absence haunts the nesting geographies of re-colonising Scottish ospreys.

634 Before concluding, I argue that encounters with past osprey culture in the present

635 are both possible and necessary in the context of technoscientific discussions of 636 'genetic rescue' (Heatherington, 2012), rewilding (Lorimer and Dreissen, 2014), and

637 even 'de-extinction' (van Dooren and Rose, 2017). Haunted landscapes evoke the 638 'present-absence' of osprey life, serving to put contemporary avian geographies 'out 639 of joint' (see Derrida, 2006). The notion of haunting emphasises the composition of 640 geographies through absence as well as presence (Wylie, 2009). Sites such as those

641 Sutherland lochs encountered by Waterston in the paper's opening - or the ruins at 642 Loch an Eilein (Figure 1) - exhibit 'shadowy density' (Pile, 2005: 142). Their ghosts 643 invite us into counter-histories; transforming, renegotiating and re-evaluating 644 celebrated pasts (Gordon, 2008: 8). Taking osprey culture seriously creates space 645 outside of triumphant conservation narratives to ask: what remains lost when a 646 species comes back?

647

648 Avian spectres

649 More-than-human cultural geographies are woven from the affective traces of lived 650 activities, relations and attachments. Such traces outlast the existence of their 651 authors. They are witnessed, amidst the collapse of ecological communities, as 652 animals remain drawn 'to places that no longer exist' (van Dooren, 2014: 66). At 
653 locations including Loch Awe and Loch Maree, ornithologist Robert Gray recalls, in

654 the latter half of the nineteenth century, lone ospreys 'hovering in the vicinity of 655 islets where nests were formerly placed' (Gray, 1871: 18-19). Similarly, at Loch an 656 Eilein, single birds appeared for three years following the last successful breeding 657 (Cash, 1914: 157). These ghosts map more-than-human geographies of absence 658 affected by extinction. Osprey site faith manifests as a performative trace of the pan659 generational work of pairs to invest in and maintain meaningful places. Spectral 660 birds conveyed the futility of such work in Gray's time of writing. They signal that 661 the loss of 'connectivity and mutuality' required to sustain communities often 662 precedes their 'final death' (Rose, 2012: 138).

663

664 Cultural expressions of avian life also haunted encounters with re-colonising 665 ospreys. In 1955, word reached George Waterston in Edinburgh, newly recruited by 666 the RSPB, of the species' potential return. Travelling to Speyside to investigate, his 667 tentative plans, sketched in conversation with local landowners and Nature 668 Conservancy representatives, were guided by an understanding of past osprey 669 cultural geographies. He assumed the birds would surely attempt to nest on Loch an

670 Eilein's ruins - the site now home to a large jackdaw colony (Corvus monedula) 671 requiring removal before re-colonisation could occur ('Ospreys at Loch Garten’, 2 672 July 1955). Upon their return, however, it became clear the birds had different 673 interests. Failing to breed in 1956 and 1957, eventually a pair settled atop a Scot's 674 pine in the marshland south of Loch Garten. Following the robbery of that nest, they 675 colonised another tree northeast of the loch in 1959. There they succeeded in rearing 
676 chicks under RSPB guard and their kin continue to return to this day (Dennis, 2008).

677 As other ospreys began to re-colonize - all tree-nesting - Loch an Eilein remained 678 empty.

679

680 With jackdaws present, the ruin was a niche closed in ecological terms. Yet the 681 enduring absence of ospreys from all former rock or ruin haunts in north and west 682 Scotland (see Dennis, 1983; Thom, 198: 146) suggests such places are also no longer 683 culturally available. The orientation of contemporary birds to the landscape is 684 different. Today's ospreys are predominantly tree-nesting, like those in Scandinavia 685 from where the current community is believed to have originated (Österlof, 1977: 686 75). These birds exist 'out of line' with the dimensions of a past affective community 687 (Ahmed, 2010: 37). Culturally, they are 'strangers [...] in a familiar land' (Lambert, 688 2011: 169).

689

690 Former sites like Loch an Eilein constitute 'signifiers for the dead' (Haraway, 2016:

691 69). I extend to place this concept developed by Haraway, after science fiction writer 692 Orson Scott Card, to characterise the spectral baggage that accompanies creatures 693 which, having evolved through symbiotic partnership, later find themselves 694 abandoned after extinction. She uses the example of an orchid, its flower continuing 695 to imitate the sexual organs of the now-absent bee once pollinating its kin. In a 696 similar vein, writer Connie Barlow discusses 'ecological anachronisms' like the 697 avocado. Characteristically large seeds and thick, oily flesh evoke the ghostly 698 presence of the long-extinct jungle herbivores once facilitating seed dispersal 
699 (Barlow, 2000). In the landscape the materiality of a previous osprey affective 700 ecology outlasts the birds' annihilation. These ruins and rocks, apparently 701 unrecognisable to contemporary ospreys, can still offer $u s$ a meaningful encounter 702 with past avian lives.

703

704 Haunted geographies

705 Appreciating a historical, cultural osprey existence attunes one in potentially 706 transformative ways to contemporary avian lives and landscapes. Annually in the 707 UK, the number and range of pairs expands (now 300 - Dennis, 2016, pers. comm.). 708 This growth has been aided by the construction of new nest sites since the 1970s, to 709 which ospreys increasingly adapt (Dennis, 2008; 131-146). Evidence from mainland 710 Europe suggests successfully colonising such structures affects subsequent

711 geographical preferences. Young born of platform nests appear predisposed to settle 712 similar sites elsewhere (Henny and Kaiser, 1996). Nearly $40 \%$ of ospreys in the

713 Scottish Highlands utilise human (re)constructed platforms over osprey-constructed

714 sites (Dennis, 2008: 142). They appear more tolerant of humans and elsewhere show 715 interest in landscape objects like utility pylons (R. Thaxton, 2014 - pers. comm.). 716 Arguably, a 'cultural shift' has occurred (Dennis, 2008: 130). The expansion of 717 conservation involvement with ospreys in the UK over the twentieth century 718 propagates new geographical associations within this re-colonised community, 719 activating new forms of osprey life (Garlick, 2017). 
721 Meanwhile, ruins and rocks remain empty. On Speyside, attention to osprey culture

722 unsettles narratives of triumphant return. Since 1959, ospreys have nested within a 723 15-kilometre flight of Loch an Eilein. They catch their prey at the Rothiemurchus 724 estate fisheries, just four kilometres away (see Lambert, 1999). Such disjointed geographies of presence and absence haunt one another (Pile, 2005). This haunting emphasises qualitative differences in what it means to be a Scottish osprey, now and in the past.

What does this change mean? Is an absence from rocks and ruins significant? In their

730 discussion of London's declining house sparrows (Passer domesticus), Whale and

731 Ginn document the responses of local birders. One interviewee expresses sadness,

732 but not merely at encountering sparrows less frequently. Rather, their rarity means

733 that encounters with these usually convivial birds are themselves different. In the 734 absence of other sparrows, [s]omething is missing in the very appearance of sparrows themselves' (Whale and Ginn, 2017: 22). This is profoundly unsettling.

I likewise find the changes that extinction has wrought for Scottish osprey life unsettling. This is not a wish to wallow in the past or appeal to static concepts of Nature. Neither do I want to neglect the flourishing of today's birds, whose success is cause for celebration. Such nostalgia blinds us to the value of ecologies existing

741 now, despite past destruction (Tsing, 2015). But I do want the loss of nineteenthcentury osprey lives to matter. Cultural concern expands and thickens creaturely

743 presence in accounts of extinction and cautions against the arrogant presumption 
that human innovation can reverse environmental wrongs. Rendering the decline of

745 historical animal culture as a significant loss invests it with ethical value (see Butler, 2009).

748 Understanding ecological existence in terms of shared cultural relations, rather than

749 interchangeable species units serving set 'functions', means recognising that the loss

750 of one set of beings engenders a host of (often unforeseen) communal losses (Smith,

751 2013). What potential cultures - what 'lines of flight' (Deleuze and Guattari, 2013)

752 onto new forms of being - have been foreclosed upon by the eradication of this

753 osprey community? Equally, what alternative futures are now possible, following re-

754 colonisation, that were not before?

755

\section{Conclusion}

757 This paper has drawn from the work of geography and the environmental

758 humanities to position 'animal culture' - the relationally-constituted, shared orientations of a community of creatures - as a valid object of geographical inquiry.

760 Elaborated here in terms of material, embodied, affective and historically contingent 761 relations of perception, niche-building, maintenance, inheritance and site attachment, osprey cultural geographies trace the lives of birds on 'beastly', dwelt terms (after Philo and Wilbert, 2000; Johnston, 2008). I argue the lives of ospreys matter on terms more than their contributions towards overall genetic integrity or species survival. Tracing the geographies of extinction and conservation means attending to the differently lived geographies collected under general categories of 
'species'. Crafting more nuanced extinction stories stays with the trouble of

768 biopolitical conservation, and the (epistemological) violence of essentialist thought.

770 Such an argument demands a more speculative historical project, attentive to the assembling of animal agency across sites and relations (Despret, 2013). My paper

772 demonstrates the potential to inject more lively animal presences into what might 773 otherwise persist as primarily anthropocentric historical projects, regaling things 774 done to - rather than with or by - other creatures (see Howell, forthcoming). Defining

775 the limits of this project remains an on-going concern. How far might the cultural-

776 historical animal geographies proposed here be extended into the past, and what

777 challenges arise when attempting to trace the stories of creatures less expressive of a 778 certain 'archival charisma'? More specific to my argument, can more (temporally) 779 distant extinctions be made to matter ethically as those closer to hand? I invite others 780 to consider these questions. ${ }^{3}$

781

782 Crucially, appreciating the manner in which the Scottish ospreys' cultural extinction

783 haunts contemporary landscapes counters the implicit narrative of conservation's 784 'molecular turn' (Hennessey, 2015) wherebyoften-distributed members of a species are collected, known and secured in terms of contributions to genetic diversity

786 (Chrulew, 2011). Encounters with genetic material offer promises of technocratic 787 redemption through re-wilding, de-domestication, and de-extinction initiatives. Yet, 788 such narratives too-often require an essentialised animal referent, comprising little

\footnotetext{
${ }^{3}$ I am grateful to an anonymous reviewer for these reflections.
} 
more than a collection of genetic traits and ecological functions; trading on classic

790 dichotomies that set animal existence apart from collaborative human becomings 791 (see Jørgensen, 2015).

792

793 Such thinking is evident in the osprey's story as early as 1949. An article

794 summarising the history of the birds in Scotland by naturalist Seton Gordon concluded that whilst their eradication was lamentable, the reader should not fear:

796 'there is no danger of this fine bird disappearing from the face of the earth' (Gordon, 797 1949: 675). Such statements engage this 'fine bird' in terms of its collective 798 population status, rather than the myriad situated forms osprey life actually takes.

799 These sentiments resonate with contemporary conservation biopolitics in which 800 threats of extinction are evaluated at the scale of the species-collective. The promise 801 of scientifically-worked atonement goes unchallenged (van Dooren and Rose, 2017).

802 As long as some creatures exist somewhere nothing has truly been lost.

803

804 I have shown how telling stories about animal cultures makes the lived specificities

805 of animal presence legible, perceptible and the subject of care. For some conservation 806 biologists, recognising animal culture might mean acknowledging our 807 responsibilities to steward more-than-human 'cultural diversity' and ensure other 808 creatures achieve 'their varied cultural potentials' (McGrew, 2009: 69). As 809 cetologists Hal Whitehead and Luke Rendell note, incorporating culture into existing 810 conservation frameworks challenges the genetic basis upon which wildlife 'stocks'

811 are been safeguarded, or sacrificed (e.g. to meet hunting quotas). For whales, 
812 'culture complicates conservation' (Whitehead and Rendell, 2015: 268). It is therefore

813 vital that more-than-human geographers engage with the arguments around the

814 existence, character, epistemology and significance of culture beyond humanity.

815

816 The return of the osprey is a story of conservation triumph. The re-colonisation of

817 Britain's skies by native raptors is widely (and rightly) celebrated (Lambert, 2011).

818 However, narratives of success must be read critically. Exploring the meaning of

819 extinction beyond the loss of biological species does not mean abandoning the idea

820 that extinction is irreversible (as some suggest - Smith-Patten et al, 2015). Rather, it is

821 to question what counts as significant loss. Given the compatibility of genetic rescue,

822 restoration and rewilding schemes with neoliberal discourse - the fear that relational

823 ontologies of nature render ecology fungible (see J. Lorimer, 2015) - I make this

824 point emphatically. No return is clean, things remain lost.

825

826 References

827 Adams W 2004 Against extinction: the story of conservation Earthscan, London

828 Ahmed S 2006 Queer Phenomenology Duke University Press, London

829 Ahmed S 2010 Happy Objects in Gregg M and Seigworth G eds The Affect Theory

830 Reader Duke University Press, London 29-51

831 Anderson K 2014 Mind over matter? On decentring the human in Human

832 Geography Cultural Geographies 21(1) 3-18 
833 Anderson K, Domosh M, Pile S and Thrift N eds 2002 Handbook of cultural geography

834 Sage, London

835 Bachelard G 1993 The Poetics of Space Beacon, Boston MA.

836 Barlow C 2000 The ghosts of evolution: nonsensical fruit, missing partners, and other

837 ecological anachronisms Basic Books, New York

838 Baxter E and Rintoul L 1953 The Birds of Scotland: Their History, Distribution, and 839 Migration Vol. 1. Oliver and Boyd, Edinburgh

840 Beattie W 1838 Scotland Illustrated Vol. 2 George Virtue, London

841 Benson E 2011 Animal Writes: Historiography, Disciplinarity, and the Animal Trace 842 in Kalof L and Montgomery G eds Making Animal Meaning Michigan State 843 University Press, East Lansing MI 3-16

844 Biermann C and Mansfield B 2014 Biodiversity, purity, and death: conservation

845 biology as biopolitics Environment and Planning D: Society and Space 32 257-73.

846 Braverman I 2015 Wild Life: The Institution of Nature Stanford University Press,

847 London

848 Brown P 1979 The Scottish Ospreys: From Extinction to Survival Heineman, London

849 Buller H 2014 Animal geographies I Progress in Human Geography 38(2) 308-18

850 Buller H 2015 Animal geographies II: Methods Progress in Human Geography 39(2)

$851 \quad 374-84$

852 Butler J 2009 Frames of War: When is Life Grieveable? Verso, New York 
853 Cameron D 1948 Recollections about the Ospreys at Achnacarry British Birds 36(9)

$854 \quad 184$

855 Cash C 1914 History of the Loch an Eilein Ospreys The Scottish Naturalist 31(July)

$856 \quad 149-58$

857 Chrulew M 2011 Managing Love and Death at the Zoo: The Biopolitics of

858 Endangered Species Preservation Australian Humanities Review 50 137-57

859 Colquhoun J 1840 The Moor and the Loch William Blackwood \& Sons, Edinburgh

860 Crist E 1999 Images of Animals: Anthropomorphism and the Animal Mind Temple

861 University Press, Philadelphia PA

862 Deleuze G and Guattari F 2013 A Thousand Plateaus: Capitalism and Schizophrenia

863 Bloomsbury, London

864 Dennis R 1983 Population Studies and Conservation of Ospreys in Scotland' in Bird

865 D ed Biology and Management of Bald Eagles and Ospreys Harpell Press, Montreal 207-

86614

867 Dennis R 1991 Ospreys Colin Baxter, Lanark

868 Dennis R 2008 A Life of Ospreys Whittles Publishing, Caithness

869 Derrida J 2006 Specters of Marx: The State of the Debt, the Work of Mourning and the New

870 International Routledge, London

871 Despret V 2004 The Body We Care For: Figures of Anthropo-zoo-genesis Body E 872 Society 10(2-3) 111-134 
874 Things Public: Atmospheres of Democracy MIT Press, London 360-9

875 Despret V 2013 From Secret Agents to Interagency History and Theory 52(4) 29-44

876 Despret V 2016 What Would Animals Say If We Asked The Right Questions? University 877 of Minesotta Press, London

878 Despret V and Meuret M 2016 Cosmoecological sheep and the arts of living on a 879 damaged planet Environmental Humanities 8 24-36

880 Ellice E 1898 Place-Names in Glengarry and Glenquoich and Their Origin Swan 881 Sonnenschein \& Co., London

882 Farber P 1997 Discovering Birds: The Emergence of Ornithology as a Scientific Discipline, 883 1760-1850 Johns Hopkins University Press, London

884 Foucault M 2003 Society must be Defended: Lectures at the Collège de France, 1975- 1976

885 Penguin, London

886 Fredriksen A 2016 Of wildcats and wild cats: Troubling species-based conservation 887 in the Anthropocene Environment and Planning D: Society and Space 34(4) 689-705

888 Garlick B 2017 Osprey Involvements: Historical animal geographies of extinction and 889 return. PhD Thesis, University of Edinburgh

890 Gilpin W 1792 Observations on the Picturesque (Vol. 2) R. Blamire, London

891 Gordon A 2008 Ghostly Matters: Haunting and the Sociological Imagination University 892 of Minnesota Press, London

893 Gordon S 1949 ‘Haunts of the Osprey' Country Life 25 March 1949 674-5 
895 Gray R 1871 The Birds of the West of Scotland Including the Outer Hebrides Thomas 896 Murray \& Son, Glasgow

897 Hansell M 2000 Bird Nests and Construction Behavior Cambridge University Press, 898 Cambridge

899 Haraway D 2008 When species meet University of Minnesota Press, London

900 Haraway D 2016 Staying with the trouble: Making kin in the Chthulucene Duke 901 University Press, London

902 Hardey J, Crick H, Wernham C, Riley H, Etheridge B and Thompson D (2009) 903 Raptors A Field Guide for Surveys and Monitoring (3 ${ }^{\text {rd }}$ Ed) Stationary Office, Edinburgh

904 Harvie-Brown J 1896 No.6 - Osprey The Society for the Protection of Birds Educational 905 Series, $1896-1898$

906 Harvie-Brown J and Buckley T 1887 A Vertebrate Fauna of Sutherland, Caithness, and 907 West Cromarty David Douglas, Edinburgh.

908 Harvie-Brown J and MacPherson H 1904 A Fauna of the North-West Highlands and 909 Skye David Douglas, Edinburgh

910 Heatherington T 2012 From Ecocide to Genetic Rescue: Can Technoscience Save the

911 Wild? in Sodikoff G ed The Anthropology of Extinction: Essays on Culture and Species

912 Death Indiana University Press, Indianapolis 39-66

913 Heise U 2010 Lost Dogs, Last Birds, and Listed Species: Cultures of Extinction 914 Configurations 18(1-2) 49-72 
915 Hennessy E 2015 The Molecular Turn in Conservation: Genetics, Pristine Nature,

916 and the Rediscovery of an Extinct Species of Galapagos Giant Tortoise Annals of the

917 Association of American Geographers 105(1) 87-104

918 Henny C and Kaiser J 1996 Osprey Population Increase along the Willamette River, 919 Oregon, and the Role of Utility Structures, 1976-93 in Bird D, Varland D and Negro 920 J eds Raptors in Human Landscapes Academic Press, London 97-108

921 Hinchliffe S 2007 Geographies of nature Sage, London

922 Hird M 2010 Meeting with the microcosmos Environment and Planning D: Society and 923 Space $2836-8$

924 Hodgetts T 2017 Wildlife conservation, multiple biopolitics and animal 925 subjectification: Three mammals' tales Geoforum 79 17-25

926 Hodgetts T and Lorimer J 2015 Methodologies for animals' geographies: cultures, 927 communication and genomics Cultural Geographies 22(2) 285-95

928 Hovorka A 2017 Animal geographies II: Hybrizing Progress in Human Geography 929 Early access, doi: 0309132517699924

930 Howell $\mathbf{P}$ forthcoming Animals, agency and history in Kean $\mathbf{H}$ and Howell $\mathbf{P}$ eds The 931 Routledge Companion to Animal-Human History Routledge, Abingdon.

932 Hustak C and Myers N 2012 Involutionary Momentum: Affective Ecologies and the 933 Sciences of Plant/Insect Encounters differences 25(3) 74-118

934 Ingold T ed 1994 What is an animal? Routledge, London. 
Ingold T 2000 The Perception of the Environment: Essays on Livelihood, Dwelling and

936 Skill Routledge, London

937 IUCN 2012 IUCN Red List Categories and Criteria Version 3.3 (2 ${ }^{\text {nd }}$ Ed) IUCN, Gland, 938 Switzerland.

939 Jardine W 1838 The Naturalist's Library, Ornithology Vol. IX, Birds of Great Britain and 940 Ireland Part 1: Birds of Prey W.H. Lizars, Edinburgh

941 Johnston C 2008 Beyond the clearing: towards a dwelt animal geography Progress in

942 Human Geography 32(5) 633-49

943 Jørgensen D 2015 Rethinking rewilding Geoforum 65 482-8

944 Kearton R 1899 Our Rarer British Birds: Their Nests, Eggs and Summer Haunts Cassell 945 and Company, London

946 Kirsch S 2014 Cultural geography II. Cultures of nature (and technology) Progress in

947 Human Geography 38(5) 691-702

948 Kitchener A 1998 Extinctions, Introductions and Colonisations of Scottish Mammals

949 and Birds since the Last Ice Age in Lambert $\mathbf{R}$ ed Species History in Scotland:

950 Introductions and Extinctions since the Ice Age Scottish Cultural Press, Edinburgh 63-92

951 Kolbert E2014 The sixth extinction: an unnatural history Bloomsbury, London

952 Laland K and Galef B 2009 Introduction in Laland K and Galef B eds The Question 953 of Animal Culture Harvard University Press, London 1-18

954 Laland K, Matthews B and Feldman M 2016 An introduction to the niche 955 construction theory Evolutionary Ecology 30 191-202 
956 Lambert R 1999 In Search of Wilderness, Nature and Sport: The Visitor to

957 Rothiemurchus, 1780-2000 in Smout C and Lambert R eds Rothiemurchus: Nature and 958 People on a Highland Estate, 1500-2000. Scottish Cultural Press, Edinburgh. 32-59.

959 Lambert R 2001 Contested Mountains: Nature, Development and Environment in the 960 Cairngorms Region of Scotland, 1880-1980. White Horse, Cambridge

961 Lambert R 2011 Strangers in a Familiar Land: The Return of the Native 'Aliens' and 962 the Re-Wilding of Britain's Skies, 1850-2010 in Rotherham D and Lambert R eds 963 Invasive and Introduced Plants and Animals: Human Perceptions, Attitudes and 964 Approaches to Management Earthscan, London 169-84

965 Lestel D 2002 The biosemiotics and phylogenesis of culture Biology and social life $966 \quad 41(1) 35-68$

967 Lestel D 2011 What Capabilities for the Animal? Biosemiotics 4 83-102

968 Lestel D 2014a Hybrid Communities Angelaki 19(3) 61-73

969 Lestel D 2014b Dissolving Nature in Culture Angelaki 19(3) 93-110

970 Lestel D, Bussolini J and Chrulew M 2014 The Phenomenology of Animal Life 971 Environmental Humanities 5 125-48

972 'Loch-an-Eilan and its Ospreys' The Scotsman 9 June 1879 Accessed via the Scotsman 973 Digital Archives, 25/2/16, BL0000540.18790609.119.0005

974 Lorimer H 2005 Cultural geography: the busyness of being more-than975 representational Progress in Human Geography 29(1) 83-94 
976 Lorimer H 2006 Herding memories of humans and animals Environment and

977 Planning D: Society and Space 24 497-518

978 Lorimer H 2009 Forces of Nature, Forms of Life: Calibrating Ethology and 979 Phenomenology in Anderson B and Harrison $\mathbf{P}$ eds Taking-Place: Non980 Representational Theories and Geography Ashgate, Farnham 55-78

981 Lorimer J 2006 What about the nematodes? Taxonomic partialities in the scope of

982 UK biodiversity conservation Social and Cultural Geography 7(4) 539-58

983 Lorimer J 2015 Wildlife in the Anthropocene: conservation after nature University of 984 Minnesota Press, London

985 Lorimer J and Driessen C 2014 Wild experiments at the Oostvaardersplassen: 986 rethinking environmentalism in the Anthropocene Transactions of the Institute of 987 British Geographers 39(2) 169-81

988 Lorimer J, Hodgetts T and Barua M 2017 Animal's atmospheres Progress in Human 989 Geography Early access, doj. 10.1177/0309132517731254

990 Lovegrove R 2007/Silent Fields: The long decline of a nation's wildlife Oxford University 991 Press, Oxford

992 Lulka D 2004 Stabilizing the herd: fixing the identity of nonhumans Environment and 993 Planning D: Society and Space 22(3) 439-63

994 Lulka D 2009 The Residual Humanism of Hybridity: Retaining a Sense of the Earth 995 Transactions of the Institute of British Geographers 34(3) 378-93

996 MacCulloch J 1824 The Highlands and Western Isles of Scotland Longman \& Co., 997 London 
998 Makrill T, Appleton T and McIntyre H 2012 The Rutland Water Ospreys Bloomsbury, 999 London.

1000 Massey D 2005 For space Sage, London

1001 Mayr E 1996 What Is a Species, and What Is Not? Philosophy of Science 63(2) 262-77

1002 McGhie H 1999 Persecution of birds of prey in north Scotland as evidenced by 1003 taxidermists' stuffing books Scottish Birds 20(2) 98-110

1004 McGowan R 2009 The decline of the Scottish Ospreys: who was to blame? Scottish 1005 Birds 29(1) 55-8

1006 McGrew W 2009 Ten Dispatches from the Chimpanzee Culture Wars, plus 1007 postscript (revisiting the battlefronts) in Laland K and Galef B eds The Question of 1008 Animal Culture Harvard University Press, London 41-69

1009 Meyburg B-U, Manowsky O and Meyburg C 1996 The Osprey in Germany: Its 1010 Adaption to Environments Altered by Man in Bird D, Varland D and Negro J eds 1011 Raptors in Human Landscapes: Adaptions to Built and Cultivated Environments Academic 1012 Press, London 125-35

1013 Midgely M 1988 Beasts, Brutes and Monsters in Ingold T ed What is an animal? 1014 Routledge, London 35-46

1015 Mitchell A 2016 Beyond Biodiversity and Species: Problematizing Extinction Theory, 1016 Culture and Society 33(5) 23-42

1017 Montagu G 1831 The Dictionary of Ornithology (2 ${ }^{\text {nd }}$ Ed.) Hirst, Chance \& Co., London.

1018 Newton I 1979 Population Ecology of Raptors T\&A Poyser, Birkhamsted 
1019 'Ospreys at Loch Morlich' 2 July 1955 Letter from George Waterston to Peter

1020 Conder, RSPB Archives, Sandy Classmark 01.05.709.

1021 Österlof S 1977 Migration, Wintering Areas, and Site Tenacity of the European

1022 Osprey Pandion h. haliaetus (L.) Ornis Scandinavica 8(1) 61-78

1023 Pearson W 1987 The Osprey Oriel Stringer, Brighton

1024 Pennant T 1771 A Tour In Scotland John Monk, Chester

1025 Philo C and Wilbert C 2000 Animal spaces, beastly places: an introduction in Philo

1026 C and Wilbert C eds Animal spaces, beastly places: new/geographies of animal-human 1027 relations Routledge, London 1-34

1028 Pile S 2005 Real Cities: Modernity, Space and the Phantasmagorias of City Life Sage, 1029 London

1030 Poole A 1989 Ospreys: A Natural and Unnatural History Cambridge University Press,

1031 Cambridge

1032 Pooley S 2015 Endangered Environmental Humanities 7(1) 259-63

1033 Pringle T 1989 The privation of history: Landseer Victoria and the Highland myth in

1034 Cosgrove D and Daniels S eds The Iconography of Landscape Cambridge University 1035 Press, Cambridge 142-61

1036 Reinert H 2013 The Care of Migrants: Telemetry and the Fragile Wild Environmental 1037 Humanities 3 1-24 
Reinert H 2015 ‘The Landscape Concept as Rupture: Extinction and Perspective in a

1039 Norwegian Fjord in Sooväli-Sepping $\mathbf{H}$, Reinert $\mathbf{H}$ and Miles-Watson $\mathbf{J}$ eds 1040 Ruptured Landscape: Landscape, Identity and Social Change Springer, London 41-54

1041 Ritchie J 1920 The Influence of Man on Animal Life in Scotland Cambridge University 1042 Press, London

1043 Rose DB 2012 Multispecies knots of ethical time Environmental Philosophy 9(1) 127-40

1044 Rose DB, van Dooren T and Chrulew M eds 2017 Extinction Studies: Stories of Time, 1045 Death and Generations Colombia University Press, New York

1046 Selby P 1836 On the Quadrupeds and Birds inhabiting the County of Sutherland, 1047 observed there during an Excursion in the Summer of 1834 Part 2 Edinburgh New 1048 Philosophical Journal 20(April 1836) 286-95

1049 Simpson W 1937 Lochaneilean Castle, Invernesshire Antiquarian's Journal 17 56-62

1050 Smith M 2013 Ecological community, the sense of the world, and senseless 1051 extinction Environmental Humanities 2(1) 21-41

1052 Smith-Patten B, Bridge E, Crawford P, Hough D, Kelly J and Patten M 2015 Is 1053 extinction forever? Public Understandings of Science 24(4) 481-95

1054 Srinivasan K 2013 The biopolitics of animal being and welfare: dog control and care 1055 in the UK and India Transactions of the Institute of British Geographers 38(1) 106-19

1056 Srinivasan K 2014 Caring for the collective: biopower and agential subjectification in 1057 wildlife conservation Environment and Planning D: Society and Space 32 501-17 
St John C 1863 Natural History and Sport in Moray: Collected from the Journals and

1059 Letters of the Charles St John Edmonston and Douglas, Edinburgh

1060 St John C 1884 A Tour in Sutherland with Extracts from the Field Books of a Sportsman 1061 and a Naturalist, Vol. 1 (2ndEd.) David Douglas, Edinburgh

1062 Steinberg M 2010 Avifaunal Research and Geographical Perspectives Geographical 1063 Review 100(2) i-iii

1064 Stewart K 2011 Atmospheric attunements Environment and Planning D: Society and 1065 Space 29(3) $445-53$

1066 Thom V 1986 Birds in Scotland T\&AD Poyser, Edinburgh

1067 Tsing A 2015 The Mushroom at the End of the World: On the possibility of life in Capitalist 1068 Ruin Princeton University Press, Oxford

1069 van Dooren T 2010 Pain of extinction: The death of a vulture Cultural Studies $1070 \quad$ Review 16(2) 271-89

1071 van Dooren T 2014 Flight Ways: Life and Loss at the Edge of Extinction Colombia

1072 University Press, New York

1073 van Dooren T 2016 Authentic crows: Identity, captivity and emergent forms of 1074 life Theory, Culture E Society 33(2) 29-52

1075 van Dooren T and Rose DB 2012 Storied-places in a multispecies city Humanimalia $1076 \quad 3(2) 1-27$ van Dooren T and Rose DB 2017 Keeping Faith with the Dead: Mourning and De1078 extinction Australian Zoologist 38(3) 375-8 
1079 Van Patter L and Hovorka A 2018 'Of place' or 'of people': exploring the animal

1080 spaces and beastly places of feral cats in southern Ontario Social $\mathcal{E}$ Cultural Geography $1081 \quad 19(2) 275-95$

1082 Waterston G 1962 The Natural History of the Osprey in Brown P and Waterston G 1083 eds The Return of the Osprey Collins, London 65-160

1084 Waterton C, Ellis R and Wynne B 2013 Barcoding Nature: Shifting Cultures of 1085 Taxonomy in an Age of Biodiversity Loss Routledge, Abingdon

1086 Whale H and Ginn F 2017 In the Absence of Sparrows in Cunsolo A and Landman 1087 K eds Mourning Nature: Hope at the Heart of Ecological Loss and Grief McGill University 1088 Press, London 92-116

1089 Whatmore S 2002 Hybrid Geographies Sage, London

1090 Whatmore S 2006 Materialist returns: practising cultural geography in and for a 1091 more-than-human world cultural geographies 13(4) 600-9

1092 Whatmore S and Thorne L 2000 Elephants on the move: spatial formations of 1093 wildlife exchange Environment and Planning D: Society and Space 18 185-203

1094 Whitehead H and Rendell L 2015 The Cultural Lives of Whales and Dolphins 1095 University of Chicago Press, London

1096 Wilson J 2007 Tales and Travels of a School Inspector Birlinn, Edinburgh

1097 Wolley J and Newton A (1864) Ootheca Wolleyana: An Illustrated Catalogue of the 1098 Collection of Birds' Eggs Formed by the Late John Wolley (Part 1: Accipitres) John Van 1099 Voorst, London 
1100 Woodward K, Jones J and Marston S 2010 Of eagles and flies: orientations toward

1101 the site Area 42(3) 271-80

1102 Wright S 2015 More-than-human, emergent belongings: A weak theory

1103 approach Progress in Human Geography 39(4) 391-411

1104 Wylie J 2009 Landscape, absence and the geographies of love Transactions of the 1105 Institute of British Geographers 34(3) 275-89

1106 Yarrell W 1871 A History of British Birds Vol. 1 (4 $4^{\text {th }}$ Ed) John Van Voorst, London

1107 Yusoff K 2012 Aesthetics of loss: biodiversity, banal violence and biotic subjects

1108 Transactions of the Institute of British Geographers 37 576-92

1109 Acknowledgements

1110 I am grateful to the editorial team at Transactions $\neg-$ particularly Simon Naylor and

1111 Fiona Nash - and to three anonymous reviewers for their constructive and generous

1112 feedback. My thanks to Lucy Schofield, for producing the map included as Figure 1;

1113 and to both Phil Howell and Thom van Dooren, for sharing draft chapters of (then)

1114 forthcoming work during the writing process. I am indebted to Pauline Couper, Phil

1115 Dodds, Louise Fellows, Eric Laurier and Fraser MacDonald for their comments and 1116 wisdom at various stages of drafting. 